\title{
Biochemical parameters of blood in fish from Zaporozhian Reservoir
}

\author{
Fedonenko Olena, Sharamok Tetyana, Ananieva Tamila*
}

\author{
Oles Honchar Dnipropetrovsk National University, Ukraine \\ Faculty of Biology, Ecology and Medicine, Department of General Biology and Water Bioresources \\ P.M.B. 49050, Dnipropetrovsk, Ukraine
}

Corresponding Email: ananievatv@mail.ru

Keywords: Zaporozhian Reservoir, biochemical parameters, blood serum, roach, prussian carp

\begin{abstract}
It had been determined the contents of total protein, albumin, glucose, urea and activity of alanine aminotransferase (ALT), aspartate aminotransferase (AST), $\alpha$-amylase in 4 -years old individuals of both sexes of prussian carp (Carassius gibelio Bloch, 1782) and roach (Rutilus rutilus Linnaeus, 1758) in different parts of the Zaporozhian Reservoir (Ukraine). The level of biochemical parameters depended on the extent of anthropogenic impact on the aquatic environment. Comparing to the prussian carp, Zaporozhian Reservoir roach was established to have a higher vulnerability to the effects of pollutants, that is why it can serve as a kind of test bioindicator for testing hydroecological system ihtiotoxicity.
\end{abstract}

\section{INTRODUCTION}

Blood, as the internal environment of the body, quickly and accurately responds to environmental change, permanently and accurately reflects the physiological state of the body, indicating the nature and severity of abnormalities. This is a sensitive and informative status indicator defenses animals $[1 ; 2]$.

Along with the production parameters of fish products, great importance also has its health status [3-6].

In addition, researching of blood parameters will make it possible to understand the biological and ecological characteristics of certain species of fish depending on their age and gender [7-11].

It is possible to get information about the condition of hydroecosystem from the biochemical parameters of fish blood. Blood quickly responses to the effects of various adverse factors and can serve as one of the early indicators of breach of fish's condition under the terms of pollution. This allows not only to evaluate and predict the environmental consequences of breaching the quality of the water environment, but also to develop methods for optimizing fish production in ponds $[1 ; 12-$ 14]. Researching the blood allows to determine the adaptive capacity of fish in specific water bodies and blood picture can be used as a standard of ecological and physiological condition of the fish during the period of active anthropogenic impact on water $[10 ; 13 ; 15 ; 16]$.

Understanding of the mechanisms of fish adaptation to living conditions promotes to hematological parameters adaptations of fish researching with different degrees of anthropogenic impact reservoirs.

\section{MATERIALS AND METHODS}

Researches were conducted in Zaporozhian Reservoir - the multi-purpose reservoir, which occupies a leading place among Ukrainian fishery ponds. According to the results of long-term monitoring studies zones with varying degrees and types of anthropogenic impact were found in the waters of the reservoir $[17 ; 18]$.

Researches were taken in two parts of the reservoir, which differ in their ecological and hydrological conditions, are the main spawning areas and the most industrial mastered reservoirs. The lower section of the reservoir near the villages Liubymivka and Viyskove characterizes with satisfactory water exchange, located in the agricultural zone and barely feels the impact of toxic 
industrial waste. Samara Bay at the confluence of the Samara River in the reservoir is characterized with low flowage and a large area of shallow water, which leads to a water "bloom" and congestion. Its hydroecological mode is determined by the impact of highly mine wastewater. The main components of polluting mine water are suspended substances and heavy metals. This area is characterized by high reservoir water mineralization $(2.8 \mathrm{~g} / \mathrm{l})$.

Both sexes of 4-year prussian carp (Carassius gibelio Bloch, 1782) and common roach (Rutilus rutilus Linnaeus, 1758) were the objects of research. Material for the research was collected during the research catching in the autumn using gill nets. Blood were collected from the tail vein. Blood samples were centrifuged at $3000 \mathrm{rpm}$ for $10 \mathrm{~min}$.

Biochemical researches were conducted on automatic analyzers OLYMPUS AU400 and AU480 of Beckman Coulter (US), by Beckman Coulter reagents in the laboratory "INVITRO" in Dnipropetrovsk. Methods for determining the activity of alanine aminotransferase (ALT), aspartate aminotransferase (AST), $\alpha$-amylase and total protein, albumin, glucose and urea are based on the recommendations of the International Federation of Clinical Chemistry (IFCC).

The data was analyzed as Mean \pm S.E.M. at reliability $95 \%$ and significant level of $\mathrm{P}<0.05$. In order to test the significant of the test, $\mathrm{t}$-test method was used.

\section{RESULT AND DISCUSSION}

The blood biochemistry indicators of prussian carp and roach caught from the two plots of Zaporizhian reservoir, indicating the water-salt, protein metabolism, which indicate the physiological state of the organism were researched.

The concentration of serum protein in fish's blood is an indicator of the general state of their health. According to the results of our research, level of total protein in serum of silver carp's blood from the lower part of Zaporizhian reservoir ranged from $38.1 \pm 5.5 \mathrm{~g} / 1$ near Liubymivka to $48.5 \pm$ $6.2 \mathrm{~g} / \mathrm{l}$ near Viyskove (Fig. 1). In roach protein content ranged from $42.6 \pm 9.7$ to $56.7 \pm 11.2 \mathrm{~g} / 1$ near Liubymivka and Viyskove respectively. A few researches of protein in the blood of fish show that its amount varies in large limits, not only among the whole group of fish, but also within the same species. These fluctuations are connected with metabolism and determined by the intensity and the nutrition. Physiological rate of protein blood serum contents, according to other authors, is $59.0 \mathrm{~g} / 1$ for roach and $27-56 \mathrm{~g} / 1$ for prussian carp. The high protein content within the established norms is a favorable sign; significant losses of protein are associated with a decrease in viability and may be accompanied by loss of fish. Low values indicate depletion, infectious diseases, kidney damage [14].

In Samara Bay total protein in serum were $80.5 \pm 9.5 \mathrm{~g} / 1$ in prussian carp and $83.1 \pm 13.5 \mathrm{~g} / \mathrm{l}$ in roach that prevailed normal value. The concentration of protein increased in both species respectively $46.5 \%$ and $66 \%$ compared with fish caught near the village Viyskove, and almost in two times comparing with Liubymivka $(\mathrm{P}<0.05)$. The cause of elevated level of protein in the fish blood from Samara Bay can be increased content of toxic substances in the area, including heavy metals that affect the liver, which synthesizes albumin and globulins. Increased concentrations of protein in blood plasma can be caused by structural changes in the liver, which lower the aminotransferase level with the simultaneous reduction of desamidization strength [11].

The main fraction of total protein is albumin. Normally albumin fraction of the total protein should be up to $55 \%$. In the researched fish of the lower part of the reservoir, this fraction is up to $51 \%$, and for fish from Samara Bay it is conversely lowered, which can indicate an excessive water content in tissues and a breach of the functional state of the liver, where the synthesis of albumin and is detoxification processes are held [19]. Due to toxic substances albumin is primarily used for energy purposes [20] (Fig. 2). 


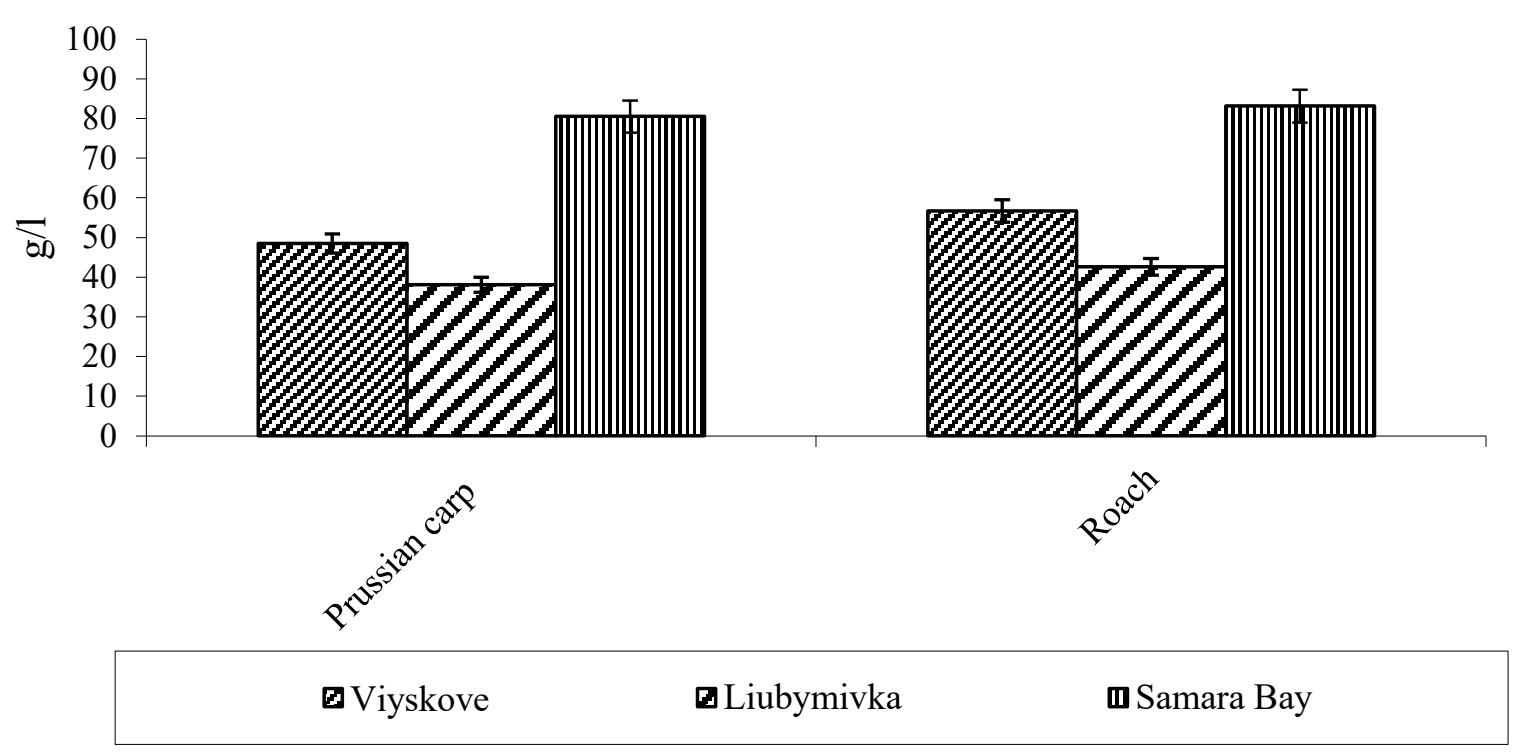

Fig.1. The protein content in blood serum of prussian carp and roach from Zaporozhian Reservoir

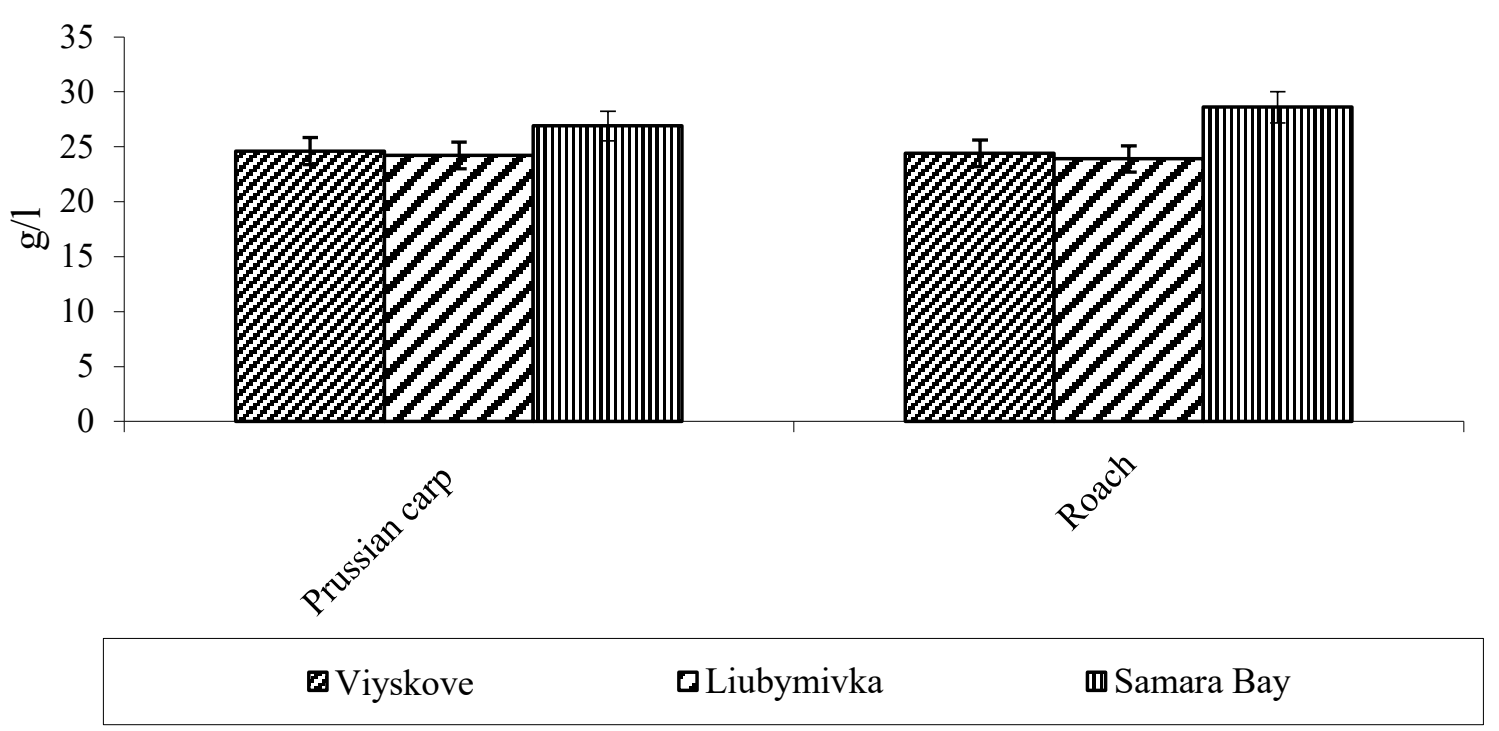

Fig. 2. The content of albumin in blood serum of prussian carp and roach from Zaporozhian Reservoir

High rates of glucose in blood serum of roach from Samara Bay were revealed. The fish caught from Samara Bay, glucose level exaggerated for 35.6\% corresponding values obtained from roach near the village Viyskove, and $60.1 \%$ - near the village Liubymivka. Glucose level was higher in roach comparing to prussian carp for 30 and $69 \%$ in Viyskove and Samara Bay respectively $(\mathrm{P}<0.05)$ (Fig. 3). The increase of glucose in blood is observed with increasing glucocorticoids in body during stress conditions, with peculiarities of nutrition. This can be associated with hyperglycemia, which is caused by the heavy metals that were proved before experimentally [21]. 


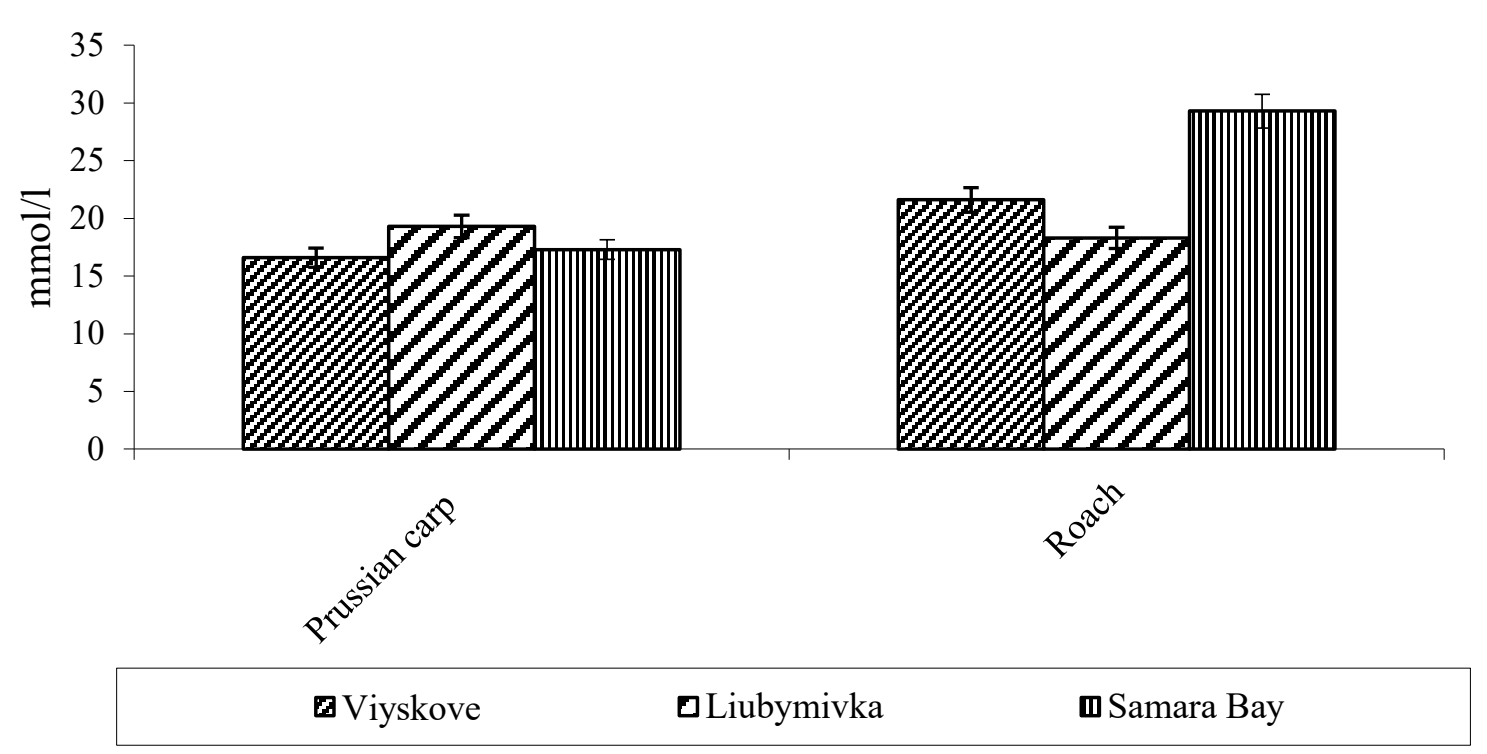

Fig.3. The content of glucose in the blood serum of prussian carp and roach from Zaporozhian Reservoir

The exchange of certain characteristics of nitrogen compounds was found in the researched fish. The content of urea in prussian carp from Samara Bay increased by $43 \%$ more than in fish from the lower part of the reservoir $(\mathrm{P}<0.05)$. A similar trend is observed in roach $(\mathrm{P}>0.05)$. Significantly bigger content $(39 \%)$ in blood serum urea of prussian carp from Samara Bay compared to roach was set (Fig. 4). Increased urea level can indicate more charge on the kidneys in fish from the Samara Bay, which can be caused by bigger human pressure on the investigated area. Toxins reduce urea excretion by the kidneys and contribute to its accumulation in the blood [20].

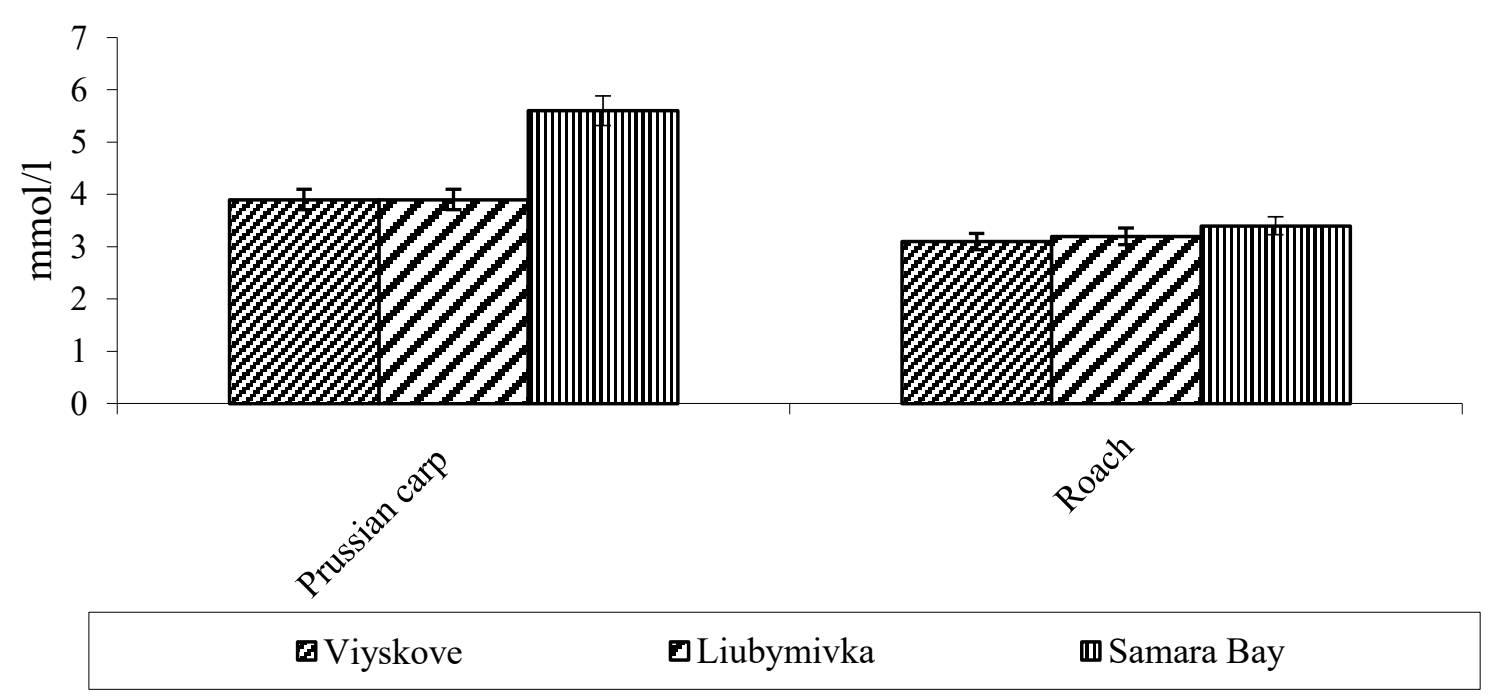

Fig. 4. The content of urea in the blood serum of prussian carp and roach Zaporozhian Reservoir

The activity of $\alpha$-amylase in serum of researched fish caught near the villages Viyskove and Liubymivka, varied considerable from $268.8 \pm 45.3$ to $303.9 \pm 35.1 \mathrm{U} / 1$ for prussian carp and from $549.8 \pm 46.9$ to $986.2 \pm 32.6 \mathrm{U} / 1$ for roach (Fig. 5). In Samara Bay $\alpha$-amylase activity level in blood of prussian carp and roach prevailed in $43.0-66.4 \%$ following indicators of fish from the lower part of the reservoir, which can indicate liver dysfunction due to significant toxic charge and adverse conditions. Also, roach has significantly higher amylase content than prussian carp to $44.0-69.0 \%$ $(\mathrm{P}<0.05)$. 


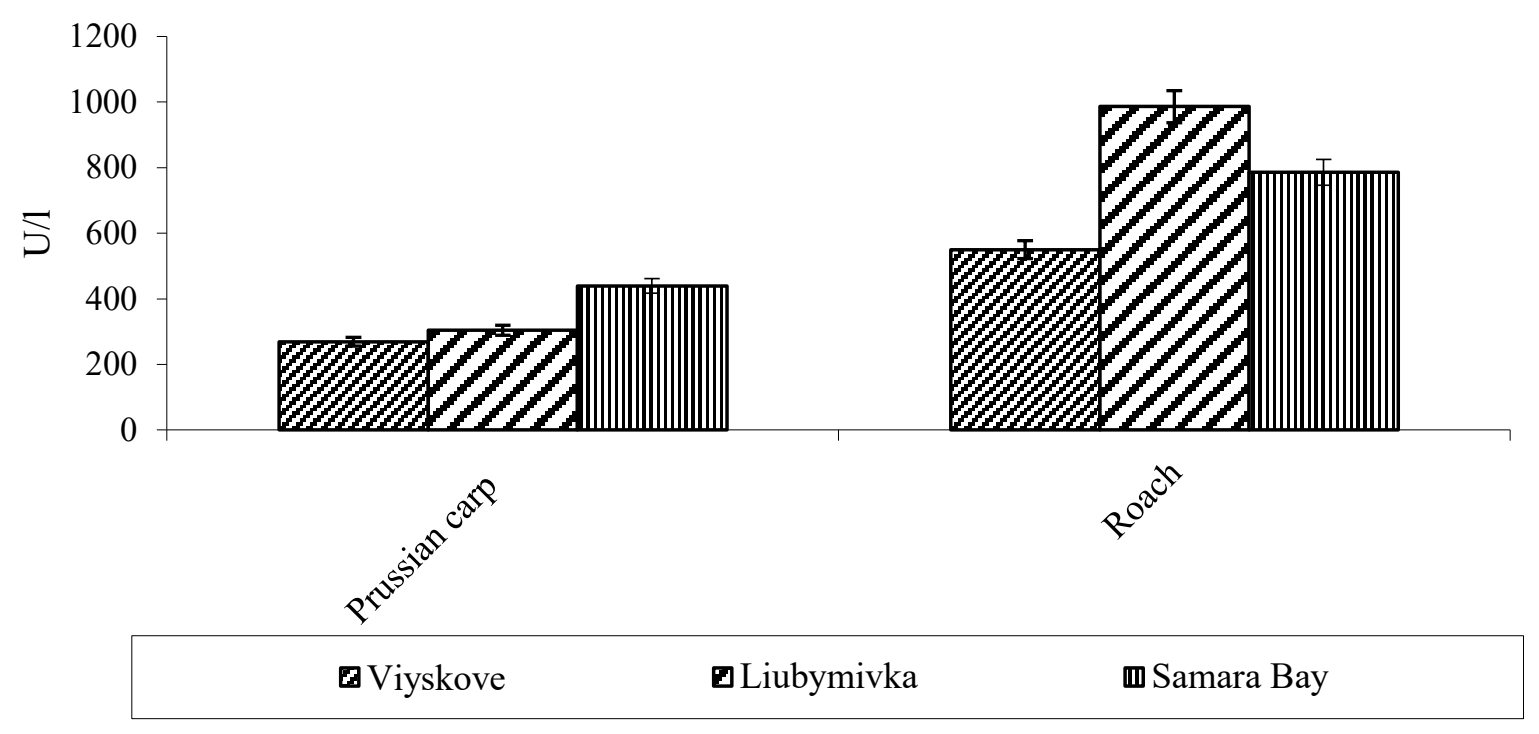

Fig. 5. Alpha-amylase activity in blood serum of prussian carp and roach from Zaporozhian Reservoir

Increased activity of alanine aminotransferase (ALT) and aspartate aminotransferase (AST) are the markers that indicate abuse and damage of muscles, liver and other internal organs [12;23]. The results show that indicators of ALT activity in blood serum of prussian carp from Samara Bay exceeded for $47.3 \%$ the rate of fish caught near the village Viyskove, and for $72.4 \%$ than near the village Liubymivka. In roach indicators ALT activity in Samara Bay were higher than ALT activity level in fish near the village Viyskove and Liubymivka respectively for 33.9 and $57.8 \%$ (Fig. 6). AST activity of prussian carp from Samara Bay did not changed significantly compared with the lower section, but in roach indicators AST activity in serum exceeded the $57.4 \%$ rate of fish caught near the village Viyskove, and 76.9\% - near the village Liubymivka (Fig. 7).

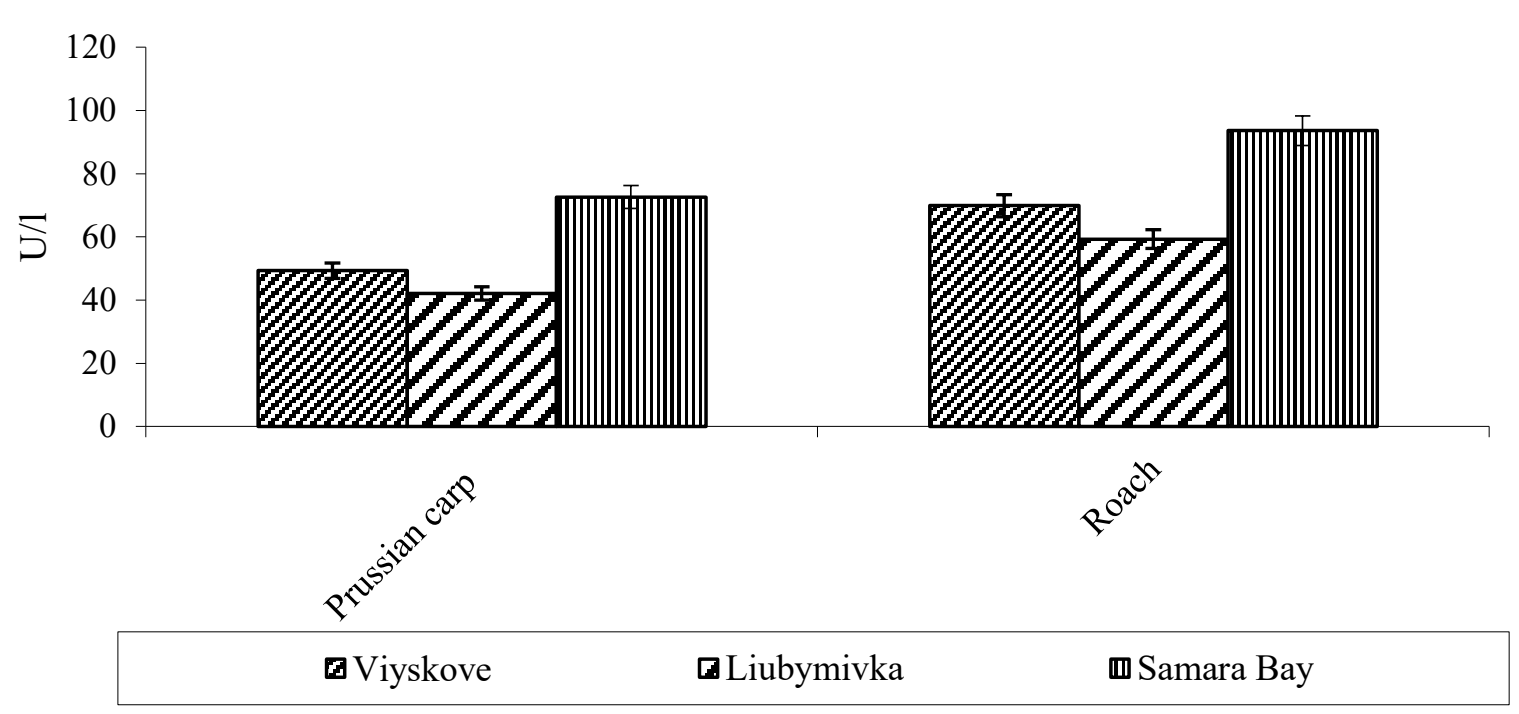

Fig. 6. Alanine aminotransferase activity (ALT) in blood serum of prussian carp and roach from Zaporozhian Reservoir 


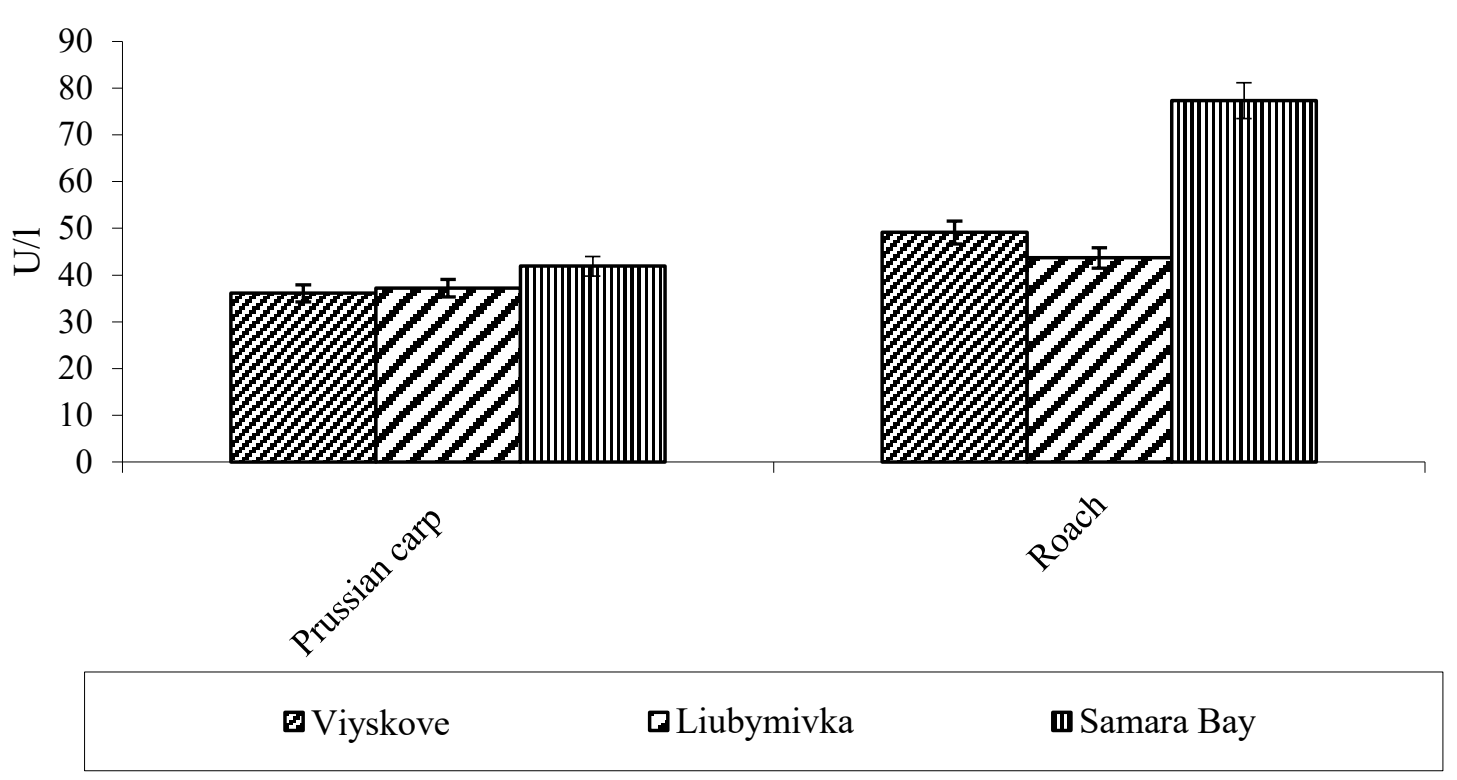

Fig. 7. Aspartate aminotransferase activity (AST) in blood serum of prussian carp and roach from Zaporozhian Reservoir

Specific features of ALT and AST activity in blood serum of researched fish was Established, as it is shown by other researchers [22]. Thus, the activity of these enzymes was significantly lower in for prussian than forcarp roach - ALT $22-29 \%$ and AST $-15-46 \%$ in different parts of the reservoir.

\section{CONCLUSION}

Thus, statistically significant deviations of the protein content, activity of $\alpha$-amylase, ALT, AST show a significant impact of toxicants on fish from the bay of Samara, primarily on the liver, which serves as a detoxification organ.

The increase in enzyme activity is a thin mechanism that is used for certain metabolic processes to adapt to adverse conditions.

Elevated rates of hepatic complex ( $\alpha$-amylase, ALT, AST) and changes in protein fractions of fish caught in the bay of Samara were identified, indicating chronic intoxication of organism.

Based on these data we can determine greater vulnerability of common roach (Rutilus rutilus, L.) from Zaporozhian Reservoir comparing to prussian carp (Carassius gibelio, B.) to the effects of pollutants, that is why it can serve as a kind of test bioindicator for testing hydroecological system ihtiotoxicity.

\section{References}

[1] F. A. Amineva, N. G. Kuramshina, Bioaccumulation of heavy metals $(\mathrm{Cu}, \mathrm{Cd}, \mathrm{Zn}, \mathrm{Pb})$ in muscles and organs of roach (Rutilus rutilus). In: Actual ecological problems: IV Int. Conf. Mater., Ufa, 2009, 7-8.

[2] O. A. Rudnitskaya, L. D. Zhytneeva, S. G. Sergeeva, Using the hematological method for the determination of physiological status disorders in producers of roach and pike-perch, Ecol. Probl.of Kuban'. 12(2001) 198-201.

[3] M. Nikoo, B. Falahatkar, M. Alekhorshid, B. N. Haghi, A. Asadollahpour, M. Z. Dangsareki, H. F. Langroudi, Physiological stress responses in kutum Rutilus frisii kutum subjected to captivity, International Aquatic Research. 2(2010) 55-60. 
[4] N. De Pedro, A. E. Guijarro, M. A. Lopez-Patino, R. Marinez-Alvarez, M. Delgado, Daily and seasonal variation in haematologicaland blood biochemical parameters in tench Tinca tinca, Aquaculture Res. 36(2005) 85-96.

[5] R. Atanasova, L. Hadjinikolova, L. Nikolova, Investigations on the biochemical composition of carp fish (Cyprinidae) blood serum at conditions of organic aquaculture, Bulg. J. Agric. Sci., 14(2008) 117-120.

[6] Z. Xiaoyun, L. Mingyun, A. Khalid, W. Weinmin, Comparative of haematology and serum biochemistry of cultured and wild Dojo loach Misgurnus anguillicadatus, Fish Physiol. Biochem. $35(2009)$ 435-441.

[7] A. Svetina, Z. Matasin, A. Tofant, M. Vucemilo, N. Fijan, Haematology and some blood chemical parameters of young carp till the age of three years, Acta Veterinaria Hungarica. 50(2002) $459-467$.

[8] Consideration of Blood Serum Biochemical Parameters of Yellow Fin Sea Bream (Acantopagrus latus Houttuyn, 1782) and Orange-Spotted Grouper (Epinephelus coioides Hamilton, 1822), Advances in Biological Chemistry, 4(2014) 407-413. Published Online October 2014 in SciRes. http://www.scirp.org/journal/abc http://dx.doi.org/10.4236/abc.2014.46046.

[9] G. Acharya1, P. K. Mohanty, Haematological and serum biochemical parameters in different sexes of walking cat fish, Clarias batrachus (Linnaeus, 1758), International Journal of Science and Research (IJSR). 3(2014).

[10] M Nicula. et. al, Researches Concerning Reference Values Assessment of Serum Biochemical Parameters in some Fish Species from Acipenseridae, Cyprinidae, Esocidae and Salmonidae Family, Scientific Papers: Animal Science and Biotechnologies. 43(2010).

[11] P. Satheeshkumar, G. Ananthan, D. S. Kumar, L. Jagadeesan, Haematology and biochemical parameters of different feeding behaviour of teleost fishes from Vellar estuary, India. In: Comp. Clin. Pathol., Springer-Verlag, London Limited, 2011.

[12] E. Ş. Çelik, H. Kaya, S. Yilmaz, M. Tavares-Dias, F. R. Moraes, Changes in Hematological and Biochemical Parameters of European Chub (Squalius cephalus L.) in Unpolluted Reservoir and Polluted Creek, Haematological and Biochemical Reference Intervals for Farmed Channel Catfish, Journal of Fish Biology. 71(2007) 383-388.

[13] F. Fazio, S. Marafioti, F. Arfuso, G. Piccione, C. Faggio, Comparative study of the biochemical and haematological parameters of four wild Tyrrhenian fish species, Veterinarni Medicina. 58(2013) 576-581.

[14] F. H. Biktasheva, Biochemical parameters of the fish blood in Aslykul lake (Russia, Bashkortostan Republic), Mezhdunarodnyi zhurnal prikladnykh i fundamentalnykh issledovaniy. 9(2010) 107-108.

[15] E. Cataldi, P. Di Marco, A. Mandich, S. Cataudella, Serum parameters of Adriatic Sturgeon Acipenser naccarii (Pisces: Acipenseriformes): Effects of temperature and stress, Comparative Biochemistry and Physiology 120(1998) 273-278. 
[16] V. Akhmetova, S. Vasina, Assessment of morphological and biochemical blood picture of carps of grown in LLC «FISH FARM» Ulyanovsk District of Ulyanovsk region, Bulletin of the Ulyanovsk State Agricultural Academy. 3(2015).

[17] O. V. Fedonenko, N. B. Esipova, T. S. Sharamok, T. V. Ananieva, V. O. Yakovenko, The current problems of hydrobiology: Zaporizke Reservoir, LIRA, Dnipropetrovsk, 2012.

[18] O. V. Fedonenko, T. S. Sharamok, Environmental assessment of key areas of Zaporizhzhya Reservoir fisheris (Ukraine), Ecologicheskiy vestnik Severnogo Kavkaza. 11(2015) 45-50.

[19] F. H. Takhtaev, D. F. Takhtaeva, A method of toxicity determining in blood fish, Patent № 2108580. In: Invention: Off. Bul. 10(1998) 298.

[20] B. Yakovenko, A. Tretiak, O. Mekhed, E. Lenko, Effect of sodium lauryl sulfate on some biochemical parameters of blood carp, Naukovi zapyski Ternopilsrogo natsionalnogo pedagogichnogo universitetu. 64(2015) 772-775.

[21] R. Vinodhini, M. Narayanan, The impact of toxic heavy metals on the hematological parameters in common carp (Cyprinus carpio L.), Iran. J. Environ. Health. Sci. Eng., 6(2009) 2328.

[22] O. N. Bichareva, Activity of serum transferases in Cyprinidae fishes, Estestvennye nauki. 34(2011) 96-100.

[23] R. A. Guliev, Pecularities of blood transferases dynamics and their relationship to microelement composition of some pond fishes of Astrakhan Region, Estestvennye nauki. 34(2011) $114-117$. 